\title{
UK Policing and Change: Reflections for Policing Worldwide
}

\author{
Colin Rogers \\ Centre for Police Sciences, University of Glamorgan \\ Upper Glyntaff, Pontypridd, CF37 1AT, United Kingdom \\ Tel: 44-1443-654-260Ｅ-mail: crogers@glam.ac.uk \\ James Gravelle (Corresponding Author) \\ Centre for Police Sciences, University of Glamorgan \\ Upper Glyntaff, Pontypridd, CF37 1AT, United Kingdom \\ Tel: 44-1443-654-260Ｅ-mail: jgravell@glam.ac.uk
}

Received: December 29, $2011 \quad$ Accepted: January 30, $2012 \quad$ Published: March 1, 2012

doi:10.5539/res.v4n1p42

URL: http://dx.doi.org/10.5539/res.v4n1p42

\begin{abstract}
Policing does not exist in a social, political or economic vacuum. The change of Government in the UK and the current global economic situation has brought about the publication of several major official reports and media announcements concerning a shift in policing priorities and the delivery of policing services in England and Wales. Such changes, combined with other events has allowed those who wish changes to be introduced to the accountability and governance process of policing throughout England and Wales much more momentum, more general support than hitherto seen coupled with a more robust licence to implement reforms. Discussion surrounding the proposed reforms allows for deeper explanation and understanding of their impact, in particular the way in which such changes may impact on wider society. This may affect the way the police organisation operates and provides service to its customers, In turn influencing the sometimes delicate balance in relationships between community, partnerships and the police.
\end{abstract}

Keywords: Police reform, Accountability, Customers, Big society, Policing

\section{Introduction}

Policing in any country does not exist in a social, political or economic vacuum (Dölling 1993) and no one can be in any doubt that the police service in England and Wales, alongside other countries is currently undergoing a major transformation. Framed against a major economic downturn, organisational changes and proposed reforms to pay and conditions, the British police service is attempting to align itself to a more streamlined approach to delivering an effective, efficient and economical product to the community and others with whom the police interact. Driving these changes are a large number of important official reports and publications that will have a major impact upon thinking about the reformation of the police. Some are more wide reaching than others, whilst some are specific in content. However, they all have a common factor that of influencing policy decision makers in the way they consider the restructure of the police organisation should take place. The scale and drive of the changes envisaged for policing is unprecedented as organisational, structural and indeed philosophical ideas of how the police in this country carry out their business will be challenged and re-framed. The purpose of this article is to consider the major elements and fundamentals currently underpinning the proposed changes and reform, which will have resonance with policing agencies in an international context.

\section{Police Reform: Change, Resistance and Uncertain Consequences}

British policing has been shaped by earlier 'cycles' of reform (Reiner 2010; Savage 2007). In its everyday sense, reform suggests change or modification of a structure, approach or system without altering the fundamental social or political order underpinning it. More recently, police reform in the UK has been described as 'a programme of change instituted during the second term of the New Labour government after the 2001 general 
election signalled by a White Paper, Policing a New Century: A Blueprint for Reform' (Newburn 2007: 731). This reform in the main revolved around policing as being involved in wider participation with partners and communities on diverse matters. Currently, the present government, supported by key stakeholders such as Her Majesty's Inspector of Constabulary (HMIC), is signalling an intention to achieve what appears to be a fundamental change in policing: the official talk is of the need for 'radical' reform, system 'redesign' and organisational 'transformation' (HMIC 2010; Home Office 2010a). McNulty and Ferlie's (2004) work suggests some difficult and arguably uncomfortable lessons for would-be agents of change in the policing context. The potential for significant 'gaps' to open up between aspiration and achievement have been identified with multiple factors having the capacity to modify the process of change. Transformational change is therefore very much about achieving simultaneous and fundamental change across all dimensions of an organisation. The '7-S' framework (Pascale and Athos 1981) argues that in order for an organisation to achieve the desired state of change and/or performance, it is important that seven elements (strategy, structure, systems, shared values, style, staff and skills) are considered and aligned. 'Style', for example, is closely associated with the notion of 'culture'. Change inevitably brings with it resistance, uncertainty and opportunity (Berry et al 1995). Kotter and Schlesinger (1979) explain these outcomes in terms of 'parochial self interest,' 'low tolerance to change', 'misunderstanding' and 'different assessments of the situation.' Savage (2007) suggests that over time (with the 'Stop Sheehy' campaign of the early 1990's in the UK marking a particular developmental high-point) the police have moved from a defensive to a more aggressive stance in terms of engaging with attempts at reform. The nature and extent of the movement has also been influenced by what Savage (2007: 142) refers to as the 'organizational ethos' - how the police see themselves and their function in wider society. Presently, within the broad ambit of government-driven reforms of the police, in addition to a focus on organisational re-design to fit the new landscape of 'austerity Britain' and the 'big society', more parochial issues are now also under review including police pay, pensions and conditions. Such issues, together with other matters of direct concern to police (including technology, equipment, competing views about the 'proper' role of 'the police' and health and safety) represent perennial 'fault lines' capable of generating tensions (if not conflict) within the police service, its partners, the government and the wider community. An important area which change will have a major impact is that of accountability and governance, in particular the introduction of Police and Crime Commissioners.

\section{Police and Crime Commissioners}

The recent publication of the Home Office consultation document 'Policing in the $21^{\text {st }}$ Century: Reconnecting the police and the people' highlight potential change in the accountably and governance of the police in the UK (Home Office 2010a). The government is currently consulting on plans to introduce directly elected police and crime commissioners, create an independent police and crime panel and introduce a new National Crime Agency in what has been described as the most radical reforms to policing for at least 50 years, introducing structures familiar to counties such as the USA. Amongst the groups most vocal and concerned with the introduction of commissioners is the Association of Police Authorities (APA), who under the proposed plans will no longer exist (Home Office 2010b). In an age where the public are encouraged to engage with public sector organisations and where the 'big society' ideology, will apparently encourage participation and volunteerism by empowering communities and decentralising power through rolling back the frontier of the state, such reforms to policing will have far reaching and significant strategic implications for the delivery of policing services to consumers (Gravelle and Rogers 2010a). In times of economic unrest, societal change and political uncertainly, challenges facing the police organisation are significant (Gravelle and Rogers 2009a). Facing a real terms budget reduction of between $16-20 \%$ accompanied by significant structural reform, it will be for the police service to deliver a better service for less (Neyroud 2010, Davis 2010). Perhaps referring to the 'better for less' rather than 'more for less' statement for service delivery more accurately encapsulates the task facing all 43 police forces across England and Wales. As society becomes more individualistic and consumer orientated, it has been suggested the police service needs to be reformed to ensure they remain effective (Shaffer and Kipp 2009). Accompanying the economic situation and constant structural and procedural change facing the police service, it is highly likely that, for example, the fast approaching Olympic games being held in the United Kingdom will further complicate the policing landscape with many practitioners and commentators suggesting that now is not the best time to undertake such a radical reform programme (Pritchard 2009). However, it seems highly likely that the government will continue its proposed programme of reform in a perceived attempt to increase policing as an accountable, effective, progressive public service. 


\subsection{The current system of accountability}

Currently, responsibility for the delivery of all policing services in England and Wales is shared between three different bodies. The power sharing responsibilities are divided amongst the Home Secretary, Police Authority and the Chief Constable (Wakefield and Fleming 2009). This arrangement is commonly referred to as the tri-partite system established by the Police Act 1964 (Home Office 1964). Under this system, the Home Secretary is responsible for the overall efficiency and effectiveness of policing in England and Wales and is accountable directly to parliament. The chief constable is responsible for all operational policing decisions within the force they control with autonomy over any available resource. The third and final party involved in policing are the police authority who regulate and hold the chief constable to account. In addition to this important duty, the police authority set the strategic direction and budget. The composition of police authorities can differ, however, in most instances there are seventeen elected members (Barrett 2011). Nine elected members are from local government and are nominated to the authority. The remaining eight independent members that are included as part of the authority come from the local community and there is a requirement that at least one independent member is a magistrate. Table 1 below sets out in detail the wider role and primary responsibilities of each of the parties involved in policing within England and Wales.

Under this system, one of the current anomalies is that the Home Office, along with other politicians, can apply significant pressure on chief constables to direct resources in particular ways. However, the result of any such operational action is solely the responsibility of the Chief Constable and there seems little accountability on behalf of individual politicians. Another area of concern in the current system is the legitimacy of the Police Authority. Although it is true that members are appointed representatives, the majority of officials that form the police authority have not been directly appointed by the public as representatives of the people on policing issues. Instead, the majority of officials were elected to local government positions as councillors and not as a direct consequence of knowledge of policing matters (Wakefield and Fleming 2009). The lack of awareness among the public also raises concerns over the legitimacy of police authorities. In a survey conducted by the Cabinet Office in 2007 , only $7 \%$ of respondents indicated that if they had an issue with the delivery of policing services, they would know to contact their local police authority (Home Office 2010c). In Casey's Crime and Communities Review (Home Office 2010c), 67\% of respondents would not know who to go to if they were not happy with the delivery of local policing services. Interestingly, only $19 \%$ of respondents in an IPSOS MORI poll stated that the local councillor was the best person to hold the police to account and in a local government inquire, $48 \%$ of respondents mistrust councils whereas only $24 \%$ mistrust the police. This lack of awareness and apparent lack of transparency has almost certainly reinforced the argument for introducing directly elected crime commissioners in a number of countries (Weitzer 1995). As the public appear mainly unaware of the existence of the police authority, it is highly unlikely that the public are informed and aware of their role, or who the members are. There is also a belief that police authorities in their current state often fail to hold Chief Constables to account (Reiner 2010). In part, it is believed that the lack of powers and autonomy held by the authority combine to reinforce the position of the Chief Constable while leaving the authority little option other than to submit to the operational decisions of the Chief Constable. It would be highly unlikely, unusual and irregular that the authority would not release the policing budget or precept to chief officers. Overall, there seems to be a 'democratic deficit' surrounding police authorities and as a result, there has been over recent years growing concern over public dissuasion and disconnection with policing. Reiner has stated that police authorities 'play the piper but never made the tune' Reiner (2010), meaning that they have been undemocratically elected and under representing the public as it hold the police service to account.

\subsection{The proposed changes}

One of the primary stated objectives of the proposed reforms is to increase understanding and participation in policing by reconnecting the public with the police (Home Office 2010a). Under the new revised system, the police authority will be replaced within the tri-partite system to include instead a police and crime commissioner for each police force excluding London (Home Office 2010b). The consultation paper uses the terminology and describes the role of the police and crime commissioners as a 'mission to fight crime and anti-social behaviour' (Home Office 2010b). Therefore it appears that the commissioner will be responsible for-

- Holding the chief officer to account by ensuring the priorities set by the wider public are achieved. It will be for the commissioner to ensure that maximum efficiency, effectiveness and economic viability is attained.

- Identify, engage with and represent local communities within the force area.

- Set the policing budget and the precept (the proportion of council tax that is spent on policing) 
- Appoint the chief constable

- Where necessary dismiss the chief constable

Although the role of the commissioners is similar to the responsibilities of the police authorities as previously explored, one of the significant differences is that the commissioner will have the power to dismiss chief officers. This appears to shift and redistribute power within the tri-partite system which it is claimed will result in a fairer and more accountable arrangement. It is anticipated that the introduction of directly elected commissioners will stimulate engagement and raise awareness by becoming more transparent and ultimately more accountable and accessible to the public. Amongst the more concerning aspects of the proposals is the projected costs of implementing the reforms.

\subsection{Economic implications of change}

In times of economic hardship and flat economic growth, the financial implications of introducing crime commissioners will be significant (Audit Commission 2010; Gravelle and Rogers 2010b). If the government continued under the previous arrangement to keep police authorities, it is believed that the current system would cost between $0.5 \%-0.75 \%$ of the police budget and precept to maintain all police authorities across England and Wales (Home Office 2010c). In 2010/11 costs, this would equate to $£ 52-£ 78$ million. The government estimate that the single one-off costs associated with introducing the crime commissioners would be $£ 5$ million. However, in addition to this cost, there would be additional annual running costs which are outlined below.

The Crime Commissioners would each receive an annual salary of $£ 122,000$ with a total expenditure for all 41 commissioners of $£ 5$ million per annum. In addition to this cost, the support team functions would need to be considered. Representing in most large numbers of people within their constituencies, the commissioner will need operational support and this cost is estimated to reach between $£ 36.9$ and $£ 63$ million. The panel overseeing the commissioners would cost an additional £2million per annum and would be responsible for holding the commissioner to account and protecting the interests of the police. The government also predict that it will be necessary to have two statutory posts in place within each force area. These posts would include a head of paid staff and financial officer posts. It is estimated to cost in salaries and bonuses $£ 7.9$ million. The final associated cost of introducing the commissioners would be the cost of elections. For the purposes of calculating the annual running cost of the system, the election cost of $£ 50$ million every four years has been divided into four resulting in a total annual running cost in $2010 / 11$ prices of $£ 64.3-£ 90.4$ million, which is more than the economic cost of running the police authorities under the current tri-partite system. Given the economic projections of implementing Crime Commissioners, it therefore appears that accountability, accountability and more accountability is to be paramount to the successful implementation of the crime commissioners as communities are empowered to engage directly and easily with the police and influence the delivery of policing services (Punch 2009). With a focus on 'bottom up' accountably from communities, commissioners, police and politicians, along with a side-ways accountability from police to statutory and volunteer partners of the 'big society', the proposed reforms may be successful (Eaton 2010; Cabinet Office 2010). With a drive for cohesion, efficacy and improving social trust in communities, it will be for the police, commissioners and public to work together and create a productive and stimulating environment, drawing on creativity and experience to solve goals identified in a changing environment (Gravelle and Rogers 2009a). It is likely that the 'single point of contact' offered by commissioners will be favourable with the public as it may leave a sense of access and empowerment, however, the detail of how this will be achieved needs to be further considers throughout the consultation process. The overseeing panel will also perhaps put in place some much needed checks and balances as to ensure that too much power is not put into the hands of one elected official. There have been concerns raised by many stakeholder groups, not least police authorities and police chiefs over operational independence. It has long been the case in England and Wales that police chiefs have autonomy in the way in which they direct resources and make operational decisions. The consultation paper clearly states, however, that this principal of operational independence is 'fundamental to British policing' and the government will take every action to ensure this is maintained under the reforms (Beare and Murray 2007). This must surely then be a matter that needs to be resolved prior to introducing the Crime Commissioners and will unquestionably be a point in which consensus must be reached for the proposals to be passed. In addition to this, there will also be need for logistical considerations of how accountably will be delivered to large numbers of constituents by only one commissioner. Although the government have in some way addressed this by budgeting for operational support for commissioners, provisions will need to be made for access. The location of the offices of the commissioner within each force will also be an issue as perhaps many living or working some distance away from the offices of the commissioner may find access to their services difficult. Indeed, the size of each community commissioners represent will also differ. Budgets, number of police officers, geographical land mass 
and the number of inhabitants will all differ and it is likely that there will be little uniformity for commissioners, opening the debate on how local commissioners will be and how local priorities will be acknowledged and implemented. To successfully overcome the democratic deficit, commissioners will need to ensure they are representative of all different communities. The concerns highlighted over the proposals include eligibility of candidates to stand for the post of commissioner, with concerns being expressed over extremist political parties such as the British National Party (BNP) or the English Defence League seeking candidacy. Former police officers are disqualified from standing for the position of Commissioner for 4 years following retirement. Indeed, the policy surrounding individuals who have or have had criminal convictions be eligible to stand would also need to be examined (Home Office 2010b). Low turnout may amplify theses issues as the police and commissioners together attempt to re-engage with communities. In response, the coalition Government is attempting to re-encourage community engagement with issues surrounding policing by encouraging and developing the concept of the 'big society'.

\section{The 'Big Society' Examined}

The idea of promoting community agencies, groups and individuals in an attempt to encourage social interaction and thus produce a more cohesive society is not particularly new. Previous official documents in the UK such as Wedlock's document on social cohesion (Home Office 2006) which promoted social cohesion and crime resistant communities, have urged crime and disorder partnership agencies to engage in these types of activities. Further, the importance of social capital has been explored in the work of Robert Putnam who considers the rise of criminal activity against a backcloth of social disengagement in the USA (Putnam 2000). Recent and current governmental ideas which extend this approach have been and are still being promoted by Halpern $(2007 ; 2010)$ who served as an aide to the previous labour government and now advises the new Conservative/Liberal Democrat coalition government. In essence, the 'big society' refers to a tripartite partnership between the citizen, community and local government (Eaton 2010). This vision requires families, networks and neighbourhoods in a post modern society to formalise a working partnership that is effective and sustainable in its approach to solving problems, building social cohesion and setting priorities for Britain. In doing so, the government along with involvement of communities is set on building a 'big society' that is bigger, stronger and has more inbuilt accountability. How this equates to the practicalities of living in the UK is worthy of examination. The current government in the UK refers to the ideology of 'big society' as liberalism, empowerment, freedom and responsibly where the top down approach to government is replaced by local innovation and civic action. Critics of the government refer to the 'big society' as the 'big cop-out' being only concerned with cutting investment and saving money. This laissez faire approach to government could mean the end for 'new public management' and centralised 'performance indicators' as seen in the UK over the previous decade or so, as it will be for society and communities to assess performance. However, government insists that for the 'big society' to work, it will require significant involvement, encouragement and support from communities. Fundamentally, there are five key strands to understanding the 'big society' as identified and promoted by the current government (Cabinet Office 2010):

\section{Empowering Communities}

Specifically, the 'big society' requires local people to have a greater say in the 'construction' of their surroundings. Accompanying these new powers, local people will also have ways of saving local facilities and services that are threatened by closure if they are deemed to be fundamental to the fabric of society. Communities will apparently have the right to take over state-run services and facilities. To introduce this change, the government states it will recruit and train 'community organisers' to support the creation of neighbourhood ideas all over the UK.

\section{Action Orientated Communities}

Community involvement, philanthropy and a spirit of volunteerism are also an integral component of the 'big society' vision. The focus on civic service aims to increase and stimulate involvement from members of the communities from all socio-economic backgrounds. A 'National Citizen Service' is to be established to encourage young people to develop the skills needed in a modern society aimed to break-down negative perceptions and stimulate cohesion. In short, the government intend to stimulate individual groups to become involved in the delivery of all public services.

\section{Decentralised Power}

A drive for decentralisation and 'rolling back the frontiers of the state' are all perhaps a synonymous style of governance set by the conservative party in the UK in previous administrations. Reducing the size and influence of the state by stimulating local initiatives is perceived as key drivers in a move to establish a 'big society'. 
Greater autonomy for communities, both financially and procedurally, is likely to be seen as government moves away from micro-management or 'nano level' management and moves to a more macro management approach. This important cultural change in governance suggests that local authorities, communities and local officials will have greater discretion and influence over the direction of local policy. For example, decisions on housing and planning are likely to return to local councils in an effort to make the procedure of allocation and urban design more accountable to local people.

\section{Greater Social Enterprises}

As pluralisation and competition is to be encouraged, it is envisaged that there will be an expansion in social enterprises. Those sectors, companies, industries and organisations that have previously been operating under a monopoly or oligopoly are likely to see an increase in competition as state run functions may be shared with other social enterprises. Public-sector workers are to be encouraged to set up employee-owned co-operatives encouraging innovation and quality of service for the end user whilst being a more economically viable option for the state. Funding the 'big society' will initially come from dormant bank accounts which this believed, will provide the necessary finding for stimulating neighbourhood groups, charities and social enterprise. As previously indicated, it is however unlikely that the 'big society' ideology drive will be funded by an unlimited supply of capital and financial constraints will play a large part in their introduction and use.

\section{Information Availability}

Finally, confidence in official data and statistics has been eroded in recent years with possibly unfounded, incorrect statistics being published resulting in several official apologies being made in parliament by senior ministers. Underpinning the 'big society', the government aims to create a new culture where the public have a 'right to data' that will be published regularly in an attempt to improve accountability. It is against the contextual backcloth that policing in England and Wales will need to operate. Clearly, given the economic framework within policing in the UK, there is a substantial amount of reform in the way the police conduct their business.

\subsection{Old wine in new bottles?}

It is useful to consider the concept of the big society against the backcloth of previous governments' activities within the field of crime and disorder reduction. The 'new' philosophy of the 'big society' it is argued, can be seen as an extension of previous government's attempt to relocate responsibility for crime control from purely state owned mechanisms to the ownership of communities. Garland (2001) argues that this country has seen the development of one type of community style programme after another since the 1960s until 'the community' has become the all purpose solution to every criminal justice problem. Some of these have been viewed as being innovative and radical, seeking to respond to the concerns of citizens and enlist the help of neighbourhood residents and organisations. This ongoing attempt to extend the use of private sector and community agencies is described by Garland as a responsibilisation strategy and involves a change in the manner in which governments respond to crime and disorder. Instead of addressing crime and disorder in a direct fashion by means of police and the criminal justice sanction approach, the new approach requires a new kind of indirect action. Over the past decade or so, a new kind of crime prevention approach has been developed by western governments, especially in the UK which has seen the introduction of new strategies dependent upon such concepts as partnerships, alliances, interagency co-operation, the multi agency approach, activating citizens etc. (Rogers 2006). The primary objective appears, however, to manoeuvre responsibility for crime control onto other agencies, organisations and individuals that operate outside the criminal justice system and to persuade them to act appropriately (Hughes 2007). In this sense, therefore, the idea of the big society, whilst projected through the lens of a different political ideology than the previous decade, may be seen as a further extension of the concept of the responsibilisation strategy employed by central government. However, what the idea of the big society brings to the debate concerning community engagement is far more involvement by communities in determining what services they require. This means that partnership agencies need to review their approach to consultation and engagement to ensure that an informed public (as a result of better local information being available to them) are seen to be involved in the decision making process concerning what services should be delivered rather than being loosely involved, very often when operational decisions concerning the provision of services have been finalised (Rogers and Milliner 2010). Whilst a progressive intent can be identified in the new government's policy announcements (such as in its decision to review the widely-unpopular Antisocial Behaviour Order), there are already serious questions being raised about the future shape, capacities and trajectories of policing and its consequences for society and police. There are also important questions to be addressed about the precise meaning of key concepts and terminology used by government. The present official preoccupation with maintaining 'frontline' policing services whilst achieving 'value for money' (VFM) may give rise to significant 
difficulties (Home Office 2010a). Defining 'VFM' is likely to continue to present major difficulties as it will inevitably mean different things to different people and therefore likely to remain a site of considerable potential conflict and disagreement. Yet, as policing commentators observe (Savage 2007), the concept of VFM has a relatively long history in the context of British policing. As a concept and organising principle, it has long been associated with ideas of 'economy', 'efficiency' and 'effectiveness' though it has been mobilised and appropriated by different stakeholders in different ways for different reasons. In the present police reform debate, it is possible to discern what may be termed as the contours of an emerging 'discourse of austerity policing.' These contours can be traced through various official 'commentary' and texts such as policy proposals and political speeches. While the notion of 'discourse' will be explored further, it is enough to note here that discourses can be seen as playing a pivotal role in structuring how individuals and groups of people perceive social reality at any given moment. Discourses are relied upon by institutions, groups and individuals to define the terms of the debate, to mobilise support and to justify policy preferences. Innes (2010) notes, for example, that the present government position on police reform may be driven as much by ideological considerations as the need to reduce spending. Yet beyond this, discourses lead to differential outcomes which affect people's everyday lives in substantive ways. In this sense different discourses lead to new sets of 'winners' and 'losers' emerging in different social and economic settings.

\subsection{The future landscape}

Policing in the 'big society' will unquestionably have implications for the police service in England and Wales. It is likely that with community engagement taking precedence, the community policing paradigm that has been adopted by the police over recent years with the roll out of neighbourhood policing team will continue if not be strengthened (Rogers et al 2007). The police may need to engage with an ever empowered community as they work together in setting short, medium and long term objectives for policing within their local community (Independent 2010). Becoming more focused at a local level while operating in smaller geographical areas will possibly be of greater importance to the police if they are to facilitate the needs of the community rather that simply prescribe narrative, often enforcement led solutions. The transfer of power to the local level is likely to be difficult for both the police and community. However, to create value, mobilise wealth in terms of reciprocity and social capital and to operate efficiently, it will be for both the police and community to agree and operate under a co-operative productive mutual partnership. As local communities are likely to be part of the setting of objectives, there will be a need for greater involvement from partner agencies, particularly local authorities, charities and local co-operatives in order to address issues which the public needs to be tackles. The use of unpaid volunteers are also likely to be increased dramatically as the police attempt to offer a wide range of services in times of austerity. The concept of volunteering within the police service in the UK is not a new one. Special Constables, who are recruited from members of local communities, are unpaid, fully warranted police officers and are the archetypical volunteer in the police. However, unusually police in the UK have begun to utilise volunteers that are unpaid 'civilians', to work within the police organisation (Gravelle et al 2009b). These are members of the public who have expressed an interest in working with the police, undertaking various roles and responsibilities within the organisation; however they are not special constables, have no police powers and are unwarranted. These 'Neighbourhood Volunteers' assist when they can, as many volunteers enjoy the flexibility of supporting the service and their local community. Dependent on the role, whether administrative or involving some sort of community engagement, some volunteers work from different police stations, and others work on the street engaging with members of the public directly, engaging in Police and Communities Together (PACT) meetings, letter dropping and other operations often working alongside neighbourhood police teams and partner agencies. Although such schemes are extensively utilised throughout some police forces, there will need to be an expansion of this programme if the police are to continue to offer a wide range of services considered necessary by communities (Flanagan 2008). In the mid to long term, volunteer schemes may have a positive influence on communities in times of austerity. This will be achieved in part because of the extended partnership approach, improving confidence and co-operation. The improved relationship as well as the developed sense of ownership and inclusion may result in targets on community safety being met. As a direct consequence, this may lead to a reduction in overall crime and fear of crime leading to a reduction in the reassurance gap (McLaughlin et al 2006). Similarly, it may be that volunteering will offer only a temporary solution that requires additional oversight and management in areas such as data security, recruitment, welfare and operations. In essence to manage issues, concerns, training, recruitment, advertisement, and financial expenditure relating to volunteers. Perhaps a more sustainable and long term approach would be ensuring that partnership agencies in areas and regions that experience high rates of crime and disorder are robust which encompasses the 'big society' ideology. In terms of structure, the 'big society' will result in the devolvement of power to more local levels. The 2020 commission conclude that directly elected crime commissions will facilitate this change in structure as power 
and autonomy is transferred away from police force and basic command unit (BCU) level and back to local communities (Home Office 2010a). It is likely that the previous managerialistic, new public management mandate where the primary focus was on centralised targets will change, moving instead to more meaningful local statistics where the locally elected crime commissioner can be held to account. No longer will sanction detection rates or league tables be considered the measurement of all policing. Instead it will be public perceptions that will take precedent. The forces of Neo-liberalism and Pluralisation are likely to increase the number of policing providers in the future (Jones et al 2006). Private contractors and a move to a more European approach to policing where a significant amount of policing tasks are contracted out to private companies and industries may also be a visible change following the implantation of the 'big society'. Losing dominance in the market, it is likely police services in the UK may need to become smaller, more focused and specialised in its approach to policing. As they lose the position of dominance in an ever dynamic market, there is likely to be expansion of partner agencies through the creation of more charities, groups and enterprise are likely to be seen following the societal shifts. This will increase the importance of better partnership working between the police and other agencies as the need to share knowledge and intelligence becomes even more important (Rogers 2006; Williamson 2008). Therefore, the aim of electing commissioners in November 2012 appears to be to make the current system more democratic and for that reason encourages transparency and accountability which has apparently been a weakness of the current tri-partite model operating across England and Wales. It means that police chiefs will have to interact and work closely with commissioners as they establish their new powers and responsibilities. Further repercussions such as the implications for the statutory and volunteer partners of the police must also be considered if maximum efficiency is to be delivered, especially in times of economic uncertainty. If implemented correctly, designing out political party infighting may be an advantage overlooked by many. However, accountably must be at the centre of any reform introduced within this area. In addition, encouraging collaboration between commissioners especially on global and national issues such as terrorism, the fast approaching Olympic events and on issues surrounding wider efficiency savings such as the procurement of resources must be well thought-out. Reducing bureaucracy, providing a joined-up service, increasing public involvement and promoting democratic accountably will arguably be the criteria and measures of success of the new scheme as England and Wales moves slowly towards an elected model of policing. Clearly, whatever the outcome of the consultation process, it will be imperative that the knowledge and experience build up by the police authorities whilst carrying out their duties of holding the police to account are retained and passed on to their successor.

\section{Conclusion}

As this article has suggested, the various proposals and recommendations of official reports seem somewhat conflicting. The demands on policing in the UK and in other countries across Europe are enormous, with police officers being asked to carry out a plethora of different roles which must be recognised. Achieving results through improving trust in communities, increasing efficacy and community cohesion, reducing crime and fear of crime along with the other key areas for the police should be recognised and taken into account when introducing any reform. However, the management of the delivery of these services should also be carried out in an atmosphere where those responsible for overseeing the delivery of policing services are able to provide a flexible, cost effective response which can satisfy ever increasing and complex demands from society. With the publication of so many recommendations regarding structure, pay, conditions etc. now cascading from various bodies, policy makers in police services everywhere need to carefully ensure that any proposals are meticulously examined to prevent any miscalculations that would undermine their task. Taking a little time to reflect upon the many and various proposals therefore may well be advantageous in the long run and lessons learned from different countries may well be useful for others who find themselves in similar countries.

\section{References}

Audit Commission. (2010). Sustaining Value for Money in the Police Service. London: Audit Commission.

Barrett, H. (2011). Constitutional and Administrative Law. 8th Edition, Abingdon: Routledge.

Beare, M. \& Murray, T. (2007). Police and Government Relations: Who's Calling the Shots? Canada: University of Toronto Press.

Berry, G., Izat, J. Mawby, R. \& Walley, L. (1995). Practical Police Management. London: Police Review Publishing .

Cabinet Office. (2010). Building the Big Society. London: Cabinet Office. 
Davis, A. (2010). Living with Cuts to Public Services: How Can we Get More for Less. Journal of Public Health, $32(3), 310-11$.

Dölling, D. (1993). Community Policing: Comparative Aspects of Community Policing Orientated Police Work. Reiden: Germany, Felix-Varlag.

Eaton, G. (2010). The "Big Society": New Doubts Emerge. London: New Statesman.

Flanagan, R. (2008). Her Majesties Inspectorate for the Constabulary: Serving Communities and Individuals. HMIC, London: Central Office of Information.

Garland, D. (2001). The Culture of Control. Oxford: Oxford University Press.

Gravelle, J. \& Rogers, C. (2009a). The Economy of Policing: The Impact of the Volunteer. Policing, 4 (1), 56-63.

Gravelle, J. \& Rogers, C. (2009b). Your Country Needs You: The Economic Viability of Volunteers in the Police. Safer Communities, 8 (3), 34-38.

Gravelle, J. \& Rogers, C. (2010a). Policing in the Big Society. Police Professional, 221, 14-16.

Gravelle J. \& Rogers, C. (2010b). Tight Purse-Strings Policing and the Decline of Research. Policing Today, 16 (4), 27-29.

Halpern, D. (2007). Social Capital. Cambridge: Polity Press.

Halpern, D. (2010). The Hidden Wealth of Nations. Cambridge: Polity Press.

Her Majesty's Inspectorate of Constabulary. (2010). Valuing the Police: Policing in an Age of Austerity, Her Majesty's Inspectorate of Constabulary. London: Home Office.

Home Office. (1964). The Police Act 1964. London: The Stationery Office.

Home Office. (2006). Crime and Cohesive Communities. Research, Development and Statistics- Communities Group. London: Home Office. [Online] Available: http://rds.homeoffice.gov.uk/rds/pdfs06/rdsolr1906.pdf (September 23, 2010)

Home Office. (2010a). Policing in the 21st Century: Reconnecting Police and the People. London: The Stationery Office.

Home Office. (2010b). Policing: Police and Crime Commissioners. London: The Stationery Office.

Home Office. (2010c). Police and Crime Commissioners: Impact Assessment. London: The Stationery Office.

Hughes, G. (2007). The Politics of Crime and Community. Basingstoke: Palgrave-Macmillan.

Independent. (2010).The Big Society: a Genuine Vision for Britain's Future - or Just Empty Rhetoric? [Online] Available: http://www.independent.co.uk/news/uk/politics/the-big-society-a-genuine-vision-for-britains-future-n dash-or-just-empty-rhetoric-2030330.html (August 26, 2010)

Innes, M. (2010). Ideology Drive. Police Review, 6, 22-23.

Jones, T. \& Newburn, T. (2006). Plural Policing: a Comparative Perspective. Abingdon: Routledge.

Kotter, J. P. \& Schlesinger, L. A. (1979). Choosing Strategies for Change. Harvard Business Review, 57 (2), 106-114.

McLaughlin, E. \& Muncie, J. (2006). The Sage Dictionary of Criminology. London: Sage.

McNulty, T. \& Ferlie, E. (2004). Process Transformation: Limitations to Radical Organizational Change within Public Service Organizations. Organization Studies, 25 (8), 1389-1412.

Newburn, T. (2007). Handbook of Policing. Cullompton: Willan Publishing .

Neyroud, P. (2010). Protecting the Front Line: The Recessionary Dilemma. Policing: a Journal of Policy and Practice, 4 (1), 1-3.

Pascale, R. \& Athos, A. (1981). The Art of Japanese Management. London: Penguin Books.

Pritchard, S. (2009). Securing the 2010 Olympics. Infosecurity, 6(6), 12-15.

Punch, M. (2009). Police Corruption: Deviance, Accountability and Reforming Policing, Cullompton: Willan Publishing.

Putnam, R. (2000). Bowling Alone. London: Simon-Schuster. 
Reiner, R. (2010). The Politics of the Police, 4th Edition. London: Oxford University Press.

Rogers, C. (2006). Crime Reduction Partnerships. Oxford: Oxford University Press.

Rogers, C. \& Lewis, R. (2007). Introduction to Police Work. Cullompton: Willan Publishing.

Rogers, C. \& Milliner, A. (2010). The Big Society: Ladders of Engagement. Police Professional, 228, 16-17.

Savage, S. (2007). Police Reform: Forces For Change. Oxford: Oxford University Press.

Shaffer, D. \& Kipp, K. (2009). Developmental Psychology, 8th Edition. Belmont: Wadsworth .

Wakefield, A. \& Fleming, S. (2009). The SAGE Dictionary of Policing. London: SAGE.

Weitzer, R. (1995). Policing Under Fire: Ethnic Conflict and Police Community Relations in Northern Ireland. Albany: State University of New York Press.

Williamson, T. (2008). The Handbook of Knowledge Based Policing. Chichester: Wiley.

Table 1. Role of the tripartite system

\begin{tabular}{|c|c|c|}
\hline Police Authority & Chief Constable & Home Office \\
\hline Maintain efficient force & Responsible for direction and control & Promote efficiency \\
\hline $\begin{array}{c}\text { Agree budget, responsible for } \\
\text { expenditure }\end{array}$ & $\begin{array}{c}\text { Prepares draft budget, financial } \\
\text { management }\end{array}$ & Determines grant \\
\hline Appoints Chief Constable & Control, directs employees & Approves appointment of CC \\
\hline $\begin{array}{c}\text { Sets local objectives, consults } \\
\text { locally }\end{array}$ & $\begin{array}{c}\text { Adhere to local \& national objectives } \\
\text { and targets }\end{array}$ & $\begin{array}{c}\text { Sets national objectives, sets } \\
\text { performance levels }\end{array}$ \\
\hline $\begin{array}{c}\text { Issues local policing plan } \\
\text { Control finances for extra } \\
\text { resources }\end{array}$ & Opraft local policing plans & Receives copy of local policing plan \\
\hline
\end{tabular}

This table illustrates the role of those involved within the tripartite system.

Table 2. Potential annual costs

\begin{tabular}{|c|c|}
\hline Description of Cost & Total Annual Expenditure \\
\hline Police and Crime Commissioner Salary and Benefits & $£ 5$ Million \\
\hline Police and Crime Commissioner Support & $£ 36.9-63$ Million \\
\hline Police Crime Commissioner Panels & $£ 2$ Million \\
\hline Chief Executive Officer Salary and Benefits & $£ 7.9$ Million \\
\hline Elections (Held Every 4 Years @£50m) & $£ 12.5$ Million \\
\hline Total & $£ 64.3-90.4$ Million \\
\hline
\end{tabular}

(Adapted from Home Office 2010a)

This table illustrates the cost of introducing police and crime commissioners. 